\title{
Biocorrosion and biofilm formation in a nutrient limited heating system subjected to alternating microaerophilic conditions
}

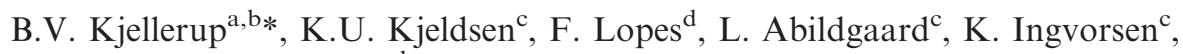 \\ B. Frølund ${ }^{\mathrm{e}}$, K.R. Sowers ${ }^{\mathrm{b}}$ and P.H. Nielsen ${ }^{\mathrm{a}}$ \\ ${ }^{a}$ Department of Biotechnology, Chemistry and Environmental Engineering, Aalborg University, Sohngaardsholmsvej 49, DK-9000 \\ Aalborg, Denmark; ${ }^{b}$ Center of Marine Biotechnology, University of Maryland Biotechnology Institute, 701 E. Pratt St, Baltimore, \\ MD 21202, USA; ' ${ }^{c}$ Department of Biological Sciences, Section for Microbiology, Aarhus University, Ny Munkegade, Building 1540, \\ DK-8000 Arhus C., Denmark; ' Department of Biological Engineering, University of Minho, Campus de Gualtar, 4710-057 Braga, \\ Portugal; ${ }^{e}$ Danish Technological Institute, Centre for Chemical and Water Technology, Teknologiparken, DK-8000 Arhus C., \\ Denmark
}

(Received 17 March 2009; final version received 10 June 2009)

\begin{abstract}
Severe biofilm formation and biocorrosion have been observed in heating systems even when the water quality complied with existing standards. The coupling between water chemistry, biofilm formation, species composition, and biocorrosion in a heating system was investigated by adding low concentrations of nutrients and oxygen under continuous and alternating dosing regimes. Molecular analysis of $16 \mathrm{~S}$ rRNA gene fragments demonstrated that the amendments did not cause changes in the overall bacterial community composition. The combined alternating dosing of nutrients and oxygen caused increased rates of pitting (bio-) corrosion. Detection of bacteria involved in sulfide production and oxidation by retrieval of the functional $d s r A B$ and aps $A$ genes revealed the presence of Gram-positive sulfate- and sulfite-reducers and an unknown sulfur-oxidizer. Therefore, to control biocorrosion, sources of oxygen and nutrients must be limited, since the effect of the alternating operational conditions apparently is more important than the presence of potentially corrosive biofilm bacteria.
\end{abstract}

Keywords: biocorrosion; biofilm; heating systems; sulfate reducing bacteria (SRB); functional genes $d s r A B$ and aps $A$

\section{Introduction}

Biofilm formation in heating systems and related problems such as biofouling and biocorrosion have for many years been considered insignificant because of good water quality with high $\mathrm{pH}$, anaerobic conditions, low conductivity, and limited nutrient availability. However, several studies have found that this is not always the case. While general corrosion rates were low, biocorrosion rates, as inferred from pitting corrosion, were generally an order of magnitude higher (Kjellerup et al. 2003; Olesen et al. 2003). Biocorrosion has been estimated to cost millions of dollars annually because of increased costs of operation and maintenance in addition to the reduced lifetime caused by perforation/corrosion of pipes and other installations (Flemming 1996).

The pretreatment of the heating water normally implies ion exchange, $\mathrm{pH}$ adjustment (9.2-10.0), and deaeration to reduce the occurrence of chemically induced corrosion. Measurements of oxygen are regularly performed showing low concentrations because the steel surfaces serve as oxygen scavengers (Heitz 1996). Oxygen may also be removed by bacterial respiration resulting in increased biofilm formation and promotion of diverse microbial populations. Biocorrosion in heating systems can occur due to the presence of many potentially corrosive groups of microorganisms such as sulfate-reducing bacteria (SRB), methanogenic Archaea, organic acid-producing bacteria, sulfur-oxidizing bacteria, iron- and manganese-oxidizing and reducing bacteria (Domingo et al. 1998; Little et al. 2000; Hamilton 2003; Rozanova et al. 2003; Zhang et al. 2003). SRB, in particular, have been related to corrosion in anoxic systems (Dinh et al. 2004; Videla and Herrera 2005) and they have been detected in the majority of heating systems investigated (Goeres et al. 1998). However, heating systems harbor diverse microbial communities and so far it has not been possible to link the occurrence of specific microbial associations and biocorrosion (Kjellerup et al. 2003, 2004, 2005; Kjeldsen et al. 2007). Although poorly understood, biocorrosion is likely the result of interplay between the activity of corrosive microorganisms and environmental physico-chemical conditions. In particular, oxygen intrusion events may play an important role because concomitant or sequential

\footnotetext{
*Corresponding author. Email: kjellerup@comb.umbi.umd.edu 
presence of reduced sulfur compounds derived from the activity of SRB and oxygen can create a corrosive environment (Lee and de Beer 1995).

Aerobic bacteria are often observed in heating systems without oxygen being detected, indicating the presence of oxygen in concentrations below the detection limit or temporarily at elevated concentrations (Kjellerup et al. 2003, 2006). Additionally, SRB have been found in aerobic environments such as activated sludge aeration tanks (Itoh et al. 2002; Kjeldsen et al. 2004) and the top layers of microbial mats (Minz et al. 1999), where they can survive and consume oxygen even though respiration with sulfate as electron acceptor does not occur (Dilling and Cypionka 1990; Krekeler et al. 1998; Teske et al. 1998). Based on this, the role SRB plays in biocorrosion of heating systems in the presence of potentially microaerophilic conditions is important.

Nevertheless, studies of the effect of water chemistry on biofilm formation, community composition, and biocorrosion in heating systems are lacking, possibly because of the technical challenges in experimentally manipulating heating systems under in situ like conditions. Such studies are important to understand and prevent biocorrosion. Until recently, little has been known about corrosive bacteria because they are difficult to grow; thus the application of culturedependent methods has been shown to be difficult to apply and has led to incorrect results and conclusions (Wagner et al. 1993; Eschenhagen et al. 2003). Therefore, the application of culture-independent techniques for detection and identification of microorganisms involved in biocorrosion is necessary. A selection of techniques has been applied to study the microbial populations in environmental samples, such as fluorescence in situ hybridization (FISH), the polymerase chain reaction (PCR), denaturing gradient gel electrophoresis (DGGE), and terminal restriction fragment length polymorphism (TRFLP) (Muyzer et al. 1993; Amann et al. 1995; Wilderer et al. 2002; Wagner et al. 2003).

This study examined whether corrosion of mild steel could be related to variations in physicalchemical conditions such as alternating concentrations of oxygen and nutrient availability in the heating water in the presence of potentially corrosive biofilm bacteria. The effect of microaerophilic conditions on biocorrosion is of special interest as large numbers of aerobic bacteria previously have been detected in heating systems without oxygen being detected, indicating the presence of oxygen in low concentrations (Kjellerup et al. 2003, 2006). This is important because the presence of microaerophilic conditions in a predominantly anaerobic system can create a very corrosive environment.

\section{Materials and methods}

\section{Operational conditions}

Corrosion monitoring units (CMUs) based on the rotortorque principle (Griebe and Flemming 2000) and equipped with mild steel coupons were installed in a side stream of the investigated heating system in Aalborg, Denmark to ensure in situ conditions throughout the experiment. This heating system was selected because of its high water quality and uninterrupted operation resulting in low in situ corrosion rates compared to other heating systems (Kjellerup et al. 2004, 2005). Therefore, this heating system was suitable for evaluating the corrosion effects caused by induced changes in the water quality.

Eight CMUs were run during the experiment to monitor biocorrosion under different conditions (Table 1). The flow through the CMUs was $\sim 11$ $\mathrm{h}^{-1}$ (hydraulic resistance time of $\sim 1 \mathrm{~h}$ ) with turbulent conditions (surface velocity of $\sim 2 \mathrm{~m} \mathrm{~s}^{-1}$ ) imitating the conditions of a heating pipe. The temperature in the return circuit ranged from 39 to $41^{\circ} \mathrm{C}$ (summer/winter). The water quality of the heating system was: $\mathrm{pH} 9.8 \pm 0.2$; conductivity $<50 \mu \mathrm{S} \mathrm{cm}{ }^{-1}$; oxygen $<10 \mu \mathrm{g}^{-1}$; chloride $<3$ $\mathrm{mg} \mathrm{l}^{-1}$; sulfate $<2 \mathrm{mg}^{-1}$; total iron $<50 \mathrm{mg}^{-1}$. Part 1 of the experiment contained five CMUs supplied with nutrients (sodium acetate and yeast extract, $5 \mathrm{mg}^{-1}$ of each), oxygen $\left(0.3 \mathrm{mg}^{-1}\right)$, or glutaraldehyde $\left(50 \mathrm{mg}^{-1}\right)$ once per day by anaerobically adding (with syringes flushed with nitrogen) as concentrated solutions as possible to minimize the added volumes, while oxygen was added via saturated heating water at $25^{\circ} \mathrm{C}$. Oxygen and nutrients were added at $12 \mathrm{~h}$ intervals to avoid growth of heterotrophic aerobic bacteria. Part 2 contained three CMUs, where nutrients were continuously added to two CMUs with different $\mathrm{pH}$ values and one CMU was run as a control without any additions. The start concentration of organic matter corresponded to five times the recommended maximum limit for Danish heating systems (Metropolitan Copenhagen Heating Transmission Company 1994), while the oxygen concentration was 15 times above the recommendation (Danish Council of District Heating 1999). These conditions simulate conditions where the heating system would be continuously contaminated from inflowing sources having a higher pressure than the heating pipe or installations, such as domestic hot water tanks or leaks of contaminated water into the system in cases of inspection, repair, or maintenance work. The concentration of glutaraldehyde applied was based on field experiments (Eager et al. 1986; Videla et al. 1991; Jack and Westlake 1995). 


\section{Sampling}

Test coupons of mild steel (SAE 1015) with a surface area of $14.3 \mathrm{~cm}^{2}(2.4 \mathrm{~cm} \times 6.0 \mathrm{~cm}$, width $\times$ height $)$, coated with an inert material on the backside and cleaned according to ASTM standard G1-90 (ASTM Standard G1-90, 1999) were inserted into the CMUs. The experiment was run for 129 days (Part 1) and 63 days (Part 2), respectively. In Part 1, sampling was also performed after 56 and 109 days. Coupons used for corrosion measurements were weighed prior to exposure and dried on site using oxygen-free $\mathrm{N}_{2}$ directly after sampling. Sampling for microbiological analyses was performed by scraping biofilm off the coupons using sterile cell scrapers (Orange Scientific) into sterile-filtered heating water (Millipore, $0.2 \mu \mathrm{m}$ pore size). Samples were fixed with formaldehyde (2\% final concentration, $\mathrm{v} / \mathrm{v}$ ) for determination of total bacterial number or with paraformaldehyde (PFA) and ethanol for FISH screening. Some coupons were evaluated with DAPI (4',6-diamidino-2-phenylindole) after scraping in order to test the efficiency of biofilm removal.

\section{Total bacterial number in biofilm samples}

Determination of the total number of bacteria in biofilm samples was performed by DAPI stain (1 mg $\mathrm{ml}^{-1}$ ) and use of epi-fluorescence microscopy according to Standard Methods (American Public Health Association/American Water Works Association/ Water Environment Federation 1995) as described by Kjellerup et al. (2005).

\section{FISH}

FISH was performed with $16 \mathrm{~S}$ and $23 \mathrm{~S}$ fluorescently labeled rRNA-targeted nucleic acid probes (Thermo Hybaid, Ulm Germany) on biofilm samples according to Amann et al. (1995) as described by Kjellerup et al. (2005). The following probes were used: EUB338-mix (bacteria) (Amann et al. 1990; Daims et al. 1999), ARCH915 (Archaea) (Stahl and Amann 1991), ALF968 (Alphaproteobacteria) (Neef 1997), BET42a (Betaproteobacteria) (Manz et al. 1992), GAM42a (Gammaproteobacteria) (Manz et al. 1992), SRB385 (Deltaproteobacteria) (Amann et al. 1990), SRB385Db (Desulfobacteriaceae within the Deltaproteobacteria) (Rabus et al. 1996), and CF319a (Cytophagales) (Manz et al. 1996). Details of the hybridization conditions and probes can be found in probeBase (Loy et al. 2003). Non-specific binding to the samples was tested by the Cy3-labeled Nonsense probe NONEUB (Wallner et al. 1993) and no signals were observed.

\section{$D G G E$ and construction of clone libraries}

DNA was extracted from biofilm scraped off coupons from CMUs 1-4 and from enrichment cultures as described elsewhere (Kjeldsen et al. 2007). DGGE analysis of bacterial 16S rRNA gene fragments was performed and $d s r A B$ clone libraries were constructed as described previously (Kjeldsen et al. 2007). Clone libraries of aps $A$ were constructed as described by Abildgaard et al. (2006) using the primers APS7-F, APS7a-F, APS7b-F, and APS8-R (Friedrich 2002) at an annealing temperature of $45^{\circ} \mathrm{C}$ for the PCR amplification of aps $A$.

\section{Phylogenetic analysis}

16S rRNA (from excised DGGE bands), $d s r A B$, and aps $A$ amplicons were sequenced, compiled, and aligned as described previously (Kjeldsen et al. 2007). Phylogenetic trees based on deduced $d s r \mathrm{AB}$ or aps $\mathrm{A}$ amino acid sequences (consisting of 435 and 242 unambiguously aligned sequence positions, respectively) were constructed by distance-matrix-based analysis using the Fitch method implemented in the ARB program package (Ludwig et al. 2004) with settings according to Friedrich (2002). Distance-matrix-based bootstrap analysis (100 replicates) was performed using PAUP* version 4.0b10 (Swofford 2003).

\section{Accession numbers}

The obtained sequences from the present study have been submitted to GenBank under the accession numbers EU156158 to EU156163 for 16S rRNA gene sequences, EU156164 to EU156166 for apsA gene sequences and EU156167 to EU156170 for $d s r \mathrm{AB}$ gene sequences.

\section{Enrichment of SRB}

Coupons, originating from CMU 1-4, from which biofilm had been scraped off, were incubated at $40^{\circ} \mathrm{C}$ in the dark in anoxic medium adjusted to $\mathrm{pH} 9.4$ to promote the growth of SRB potentially left on the coupons. The medium was based on the buffer 3[cyclohexylamino]-2-hydroxy-1-propanesulfonic acid (CAPSO, $\mathrm{p} K_{\mathrm{a}} 9.4,37^{\circ} \mathrm{C}$ ) and was prepared as described previously (Kjeldsen et al. 2007). A mixture of the following substrates $(2 \mathrm{mM}$ final concentration each) served as energy and carbon sources: acetate, lactate, propionate, ethanol, and glucose. After incubation for 1 month, the enrichment cultures were harvested for DNA extraction by centrifugation. The enriched SRB were identified by cloning and sequencing of dsrAB and aps A as described earlier. 
Table 1. Operational conditions in the CMUs.

\begin{tabular}{|c|c|c|c|c|c|c|c|c|}
\hline & \multicolumn{8}{|c|}{ Parameter } \\
\hline & \multicolumn{4}{|c|}{ Alternating dosing } & \multicolumn{4}{|c|}{ Continuous dosing } \\
\hline & 1 & 2 & 3 & 4 & 5 & 6 & 7 & 8 \\
\hline Dosing & Org & $\mathrm{O}_{2}$ & $\mathrm{Org} / \mathrm{O}_{2}$ & - & GA & - & $\mathrm{NaOH}$ & $\mathrm{NaOH}$ \\
\hline Dosing time $\left(\min\right.$ day $\left.^{-1}\right)$ & 2 & 2 & 2 & 0 & 2 & 0 & Cont. & Cont. \\
\hline Sulfate $\left(\mathrm{mg} \mathrm{l}^{-1}\right)$ & 0 & 0 & 0 & 0 & 0 & 0 & $8.2(0.4)$ & $8.2(0.4)$ \\
\hline Acetate $\left(\mathrm{mg} \mathrm{1}^{-1}\right)$ & 5 & 0 & 5 & 0 & 0 & 0 & $6.2(0.4)$ & $6.2(0.4)$ \\
\hline Yeast extract $\left(\mathrm{mg} \mathrm{l}^{-1}\right)$ & 5 & 0 & 5 & 0 & 0 & 0 & 5 & 5 \\
\hline Oxygen $\left(\mathrm{mg} \mathrm{l}^{-1}\right)$ & 0 & 0.3 & 0.3 & 0 & 0 & 0 & 0 & 0 \\
\hline Glutaraldehyde $\left(\mathrm{mg} \mathrm{l}^{-1}\right)$ & 0 & 0 & 0 & 0 & 50 & 0 & 0 & 0 \\
\hline $\mathrm{pH}$ & $10.0(0.2)$ & $10.3(0.4)$ & $10.0(0.2)$ & $9.8(0.2)$ & $9.8(0.2)$ & $9.8(0.2)$ & $8.2(0.2)$ & $9.2(0.2)$ \\
\hline Temperature $\left({ }^{\circ} \mathrm{C}\right)$ & $25(3)$ & $25(2)$ & - & $24(2)$ & - & $30^{\mathrm{a}}$ & $30^{\mathrm{a}}$ & $30^{\mathrm{a}}$ \\
\hline Flow $\left(1 \mathrm{~h}^{-1}\right)$ & $0.9(0.1)$ & $0.9(0.1)$ & $0.9(0.2)$ & $0.9(0.1)$ & $0.9(0.3)$ & $1.0(0.1)$ & $1.0(0.1)$ & $1.0(0.1)$ \\
\hline Exposure time (days) & 129 & 129 & 129 & 129 & 129 & 63 & 63 & 63 \\
\hline
\end{tabular}

The concentrations listed for the alternating conditions were obtained in the CMUs after dosing for 2 min; 1-8 represent CMU numbers; Org, organic matter; GA, glutaraldehyde.

${ }^{\mathrm{a}}$ Not measured, but controlled by an external heating system.

\section{Corrosion}

Corrosion of the mild steel coupons was investigated by measurements of weight loss and pit formation. Weight loss was assessed according to ASTM Standard G1-90 (ASTM 1999). Pit formation was determined for the individual coupons by visual inspection in combination with laser interferometry (ASTM 1994; UBM 2009) as previously described (Kjellerup et al. 2003). Statistical evaluation (Students $t$-test; $p<0.05$ ) was performed for the pitting corrosion rates with the software SigmaStat 3.0 to determine significant differences of the corrosion rates. The pitting factor (PF) was determined as the deepest metal penetration divided by the average metal penetration according to G46-94 (ASTM 1994). A PF close to 1 represents uniform corrosion and increasing numbers represents higher degree of pitting.

\section{Results}

\section{Total number of bacteria}

The highest numbers $\left(87 \times 10^{6}\right.$ cells $\left.\mathrm{cm}^{-2}\right)$ were observed when nutrients were dosed continuously at $\mathrm{pH}$ 9.2, whereas numbers 10 and 100 times lower than this were observed during alternating dosing and during control conditions, respectively (Table 2). When glutaraldehyde was added, the numbers decreased to $0.04 \times 10^{6}$ cells $\mathrm{cm}^{-2}$ (ie 100 fold). Under alternating conditions with oxygen and nutrients added individually the bacterial numbers increased over time, while a steady state was reached after 56 days when nutrients in combination with oxygen were added. In the case of continuous addition of nutrients at $\mathrm{pH} 8.2$ (CMU 7), the total bacterial numbers were similar to the CMU which experienced
Table 2. Total number of bacteria in biofilm samples from mild steel coupons.

\begin{tabular}{|c|c|c|c|}
\hline \multirow[b]{2}{*}{ Treatment } & \multicolumn{3}{|c|}{$\begin{array}{l}\text { Total number of bacteria } \\
\qquad\left(\times 10^{6} \text { cells } \mathrm{cm}^{-2}\right)\end{array}$} \\
\hline & 56 days & 109 days & 129 days \\
\hline \multicolumn{4}{|l|}{ Part 1} \\
\hline Organic matter & $1.6(0.005)$ & $1.7(0.0007)$ & $2.2(0.01)$ \\
\hline $\mathrm{O}_{2}$ & $6.3(0.03)$ & $7.0(0.01)$ & $18.4(0.04)$ \\
\hline Organic matter $/ \mathrm{O}_{2}$ & $3.1(0.005)$ & $12.2(0.04)$ & $11.8(0.03)$ \\
\hline Control & $\begin{array}{c}0.2 \\
(0.0004)\end{array}$ & $0.60(0.004)$ & $\begin{array}{c}0.5 \\
(0.0004)\end{array}$ \\
\hline Glutaraldehyde & $\begin{array}{c}0.04 \\
(0.0003)^{\mathrm{a}}\end{array}$ & $\begin{array}{c}0.05 \\
(0.00009)^{\mathrm{b}}\end{array}$ & Ns \\
\hline \multicolumn{4}{|l|}{ Part 2} \\
\hline Control & $5.6(1.9)^{\mathrm{c}}$ & Ns & Ns \\
\hline $\mathrm{pH}=8.2$ & $3.5(0.90)^{\mathrm{c}}$ & Ns & Ns \\
\hline $\mathrm{pH}=9.2$ & $87.4(14.1)^{\mathrm{c}}$ & Ns & Ns \\
\hline
\end{tabular}

The $95 \%$ confidence interval is shown; Ns: No sample due to different duration of experiments.

Sampling was performed after ${ }^{\mathrm{a}} 41$ days, ${ }^{\mathrm{b}} 94$ days and ${ }^{\mathrm{c}} 63$ days instead of the main sampling dates due to a later start.

an alternating supply of nutrients (CMU 1), while the total number increased 25 fold when the $\mathrm{pH}$ was increased to $\mathrm{pH} 9.2$ (CMU 8).

\section{Microbial diversity}

\section{FISH}

Biofilm samples from CMUs 6-8 (continuous addition) were screened with FISH to evaluate their microbial diversity (Table 3). Samples obtained from the remaining CMUs could not be analyzed with FISH even though clear signals were observed with the general nucleic acid stain DAPI for all CMUs. The 
Table 3. FISH analysis of biofilm samples from mild steel coupons showing the percentage of FISH positive cells compared with DAPI.

\begin{tabular}{lccc}
\hline & & \multicolumn{2}{c}{$\%$ of DAPI } \\
\cline { 3 - 4 } Target & Probe & $\mathrm{pH}=8.2$ & $\mathrm{pH}=9.2$ \\
\hline Nonsense probe & Non-EUB & 0 & 0 \\
Archaea & ARCH915 & 0 & 0 \\
Bacteria & Eub-mix & $55.2(4.3)$ & $63.3(2.4)$ \\
Alphaproteobacteria & ALF968 & $0.1(0.03)$ & 0 \\
Betaproteobacteria & BET42 & $17.0(1.2)$ & $15.6(2.7)$ \\
Gammaproteobacteria & GAM42a & $2.2(0.9)$ & $2.0(2.0)$ \\
Deltaproteobacteria & SRB385 & $0.3(0.2)$ & 0.1 \\
Desulfobacteriaceae & SRB385Db & $0.3(0.2)$ & 0.2 \\
Cytophagales & CF319a & $1.8(1.0)$ & $1.5(1.3)$ \\
Unidentified & - & 23.1 & 17.3 \\
\hline
\end{tabular}

The $95 \%$ confidence interval is shown.

reason might be a limited number of ribosomes in the cells because of starvation or death in the case of glutaraldehyde. More sensitive FISH techniques such as catalyzed reporter deposition-fluorescence in situ hybridization (CARD-FISH) (Pernthaler et al. 2002) were not applied because lack of signal was not anticipated since previous studies in heating systems using conventional FISH probes were successful (Kjellerup et al. 2003). Therefore, the samples were not collected and treated for that analysis. The FISH screening showed that $55-63 \%$ of the total number of bacteria could be hybridized with the general probe mix for bacteria, showing that a large proportion of the bacteria might have been inactive, dead or did not contain enough ribosomes for identification. No Archaea were detected and the major bacterial groups were proteobacteria and cytophagales with the Betaproteobacteria as the dominant group. In total, 19$22 \%$ of the total number of bacteria was identified leaving a large proportion of bacteria hybridized with the general bacterial probe unidentified. SRB, as inferred from positive hybridizations with the probes SRB385 (targeting the families Desulfovibrionaceae and Desulfobulbaceae within the Deltaproteobacteria) and SRB385db (targeting the families Desulfobacteraceae and Syntrophobacteraceae within the Deltaproteobacteria) (Stahl et al. 2007) were present (Figure 1), but in low numbers $(<1 \%$ of the total number of bacteria). Non-target bacteria could also be detected using the probes SRB385 and SRB385db (Lucker et al. 2007) resulting in false positive detection of SRB in the biofilm samples from the CMUs. Therefore, the results obtained with these probes are inconclusive in this case and the two FISH probes should be used in double hybridization with more specific SRB probes. Thus, the results obtained with these probes do not prove the presence of SRB in the biofilm samples (see belowretrieval of SRB functional genes).

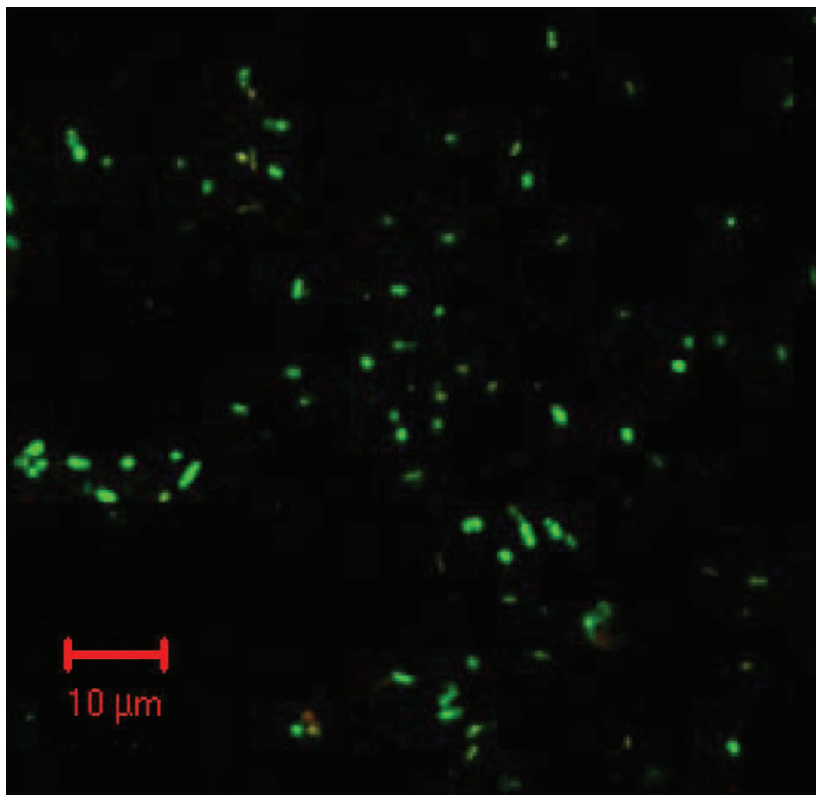

Figure 1. FISH image showing bacteria from a homogenized biofilm sample hybridized with the probes Srb385 (Green) and Srb660 (Red) targeting Deltaproteobacteria and Desulfobulbus sp., respectively. No Desulfobulbus sp. was targeted thus no red bacteria are present in the image.

\section{DGGE analysis}

The bacterial diversity of CMUs $1-4$ was evaluated by DGGE analysis of $16 \mathrm{~S}$ rRNA amplicons. Dominant bands were shared among the individual and combined treatments with oxygen and nutrients showing a large degree of commonality between the samples despite the difference in operational conditions. The six dominant bands were excised from the gel and sequenced (Table 4). Four bands represented members of the class Betaproteobacteria, whereas the two remaining bands were affiliated with Alphaproteobacteria and the phylum Chloroflexi, respectively. SRB were not identified with DGGE, which corresponds with other studies where DGGE has been shown only to detect PCR amplicons making up $>1 \%$ of the total pool of amplicons (ie community members making up $>1 \%$ of the total community) (Muyzer et al. 1993). According to the FISH results, SRB constitute $<1 \%$ of the total population and cannot be expected to be observed with DGGE. In addition, the applied FISH probes might also have hybridized non-target bacteria causing detection of false-positive SRB that would not be detected with DGGE either. Detection of specific bacterial groups present in low numbers, as might be the case with the SRB in this study, can be detected by use of specific targets such as functional genes (shown below). 
Table 4. Phylogenetic affiliation of DGGE band sequences retrieved from DGGE analysis of bacterial 16S rRNA gene fragments that were PCR amplified from biofilm samples.

\begin{tabular}{|c|c|c|c|c|c|c|}
\hline \multirow[b]{2}{*}{ Band no. } & \multirow[b]{2}{*}{ Closest match in GenBank database ${ }^{a}$} & \multirow[b]{2}{*}{$\%{ }^{b}$} & \multicolumn{4}{|c|}{$\mathrm{CMU}^{\mathrm{c}}$} \\
\hline & & & 1 & 2 & 3 & 4 \\
\hline \multicolumn{7}{|c|}{ Alphaproteobacteria } \\
\hline DGGE band 6 & Blastochloris sulfoviridis, AY117148 & 92 & $*$ & + & $*$ & - \\
\hline \multicolumn{7}{|l|}{ Betaproteobacteria } \\
\hline DGGE band 1 & Denitratisoma oestradiolicum, AY879297 & 94 & + & $*$ & $*$ & $*$ \\
\hline DGGE band 2 & Alcaligenaceae bacterium BL-169, DQ196633 & 94 & + & * & - & - \\
\hline DGGE band 3 & Caldimonas taiwanensis, AY845052 & 96 & - & + & - & - \\
\hline DGGE band 5 & Hydrogenophaga pseudoflava, AF078770 & 94 & - & + & - & - \\
\hline \multicolumn{7}{|l|}{ Chloroflexi } \\
\hline DGGE band 4 & Bellilinea caldifistulae, АВ243672 & 94 & $*$ & $*$ & + & - \\
\hline
\end{tabular}

+, Presence of DGGE band confirmed by sequencing; * , presence of DGGE band inferred by visual inspection of the DGGE gels; -, not detected. ${ }^{\mathrm{a}}$ As determined by BLAST search; ${ }^{\mathrm{b}}$ Percent sequence identity as determined by BLAST search; ${ }^{\mathrm{c}} \mathrm{CMU}$ from which coupon biofilm- or coupon enrichment-sample originates.
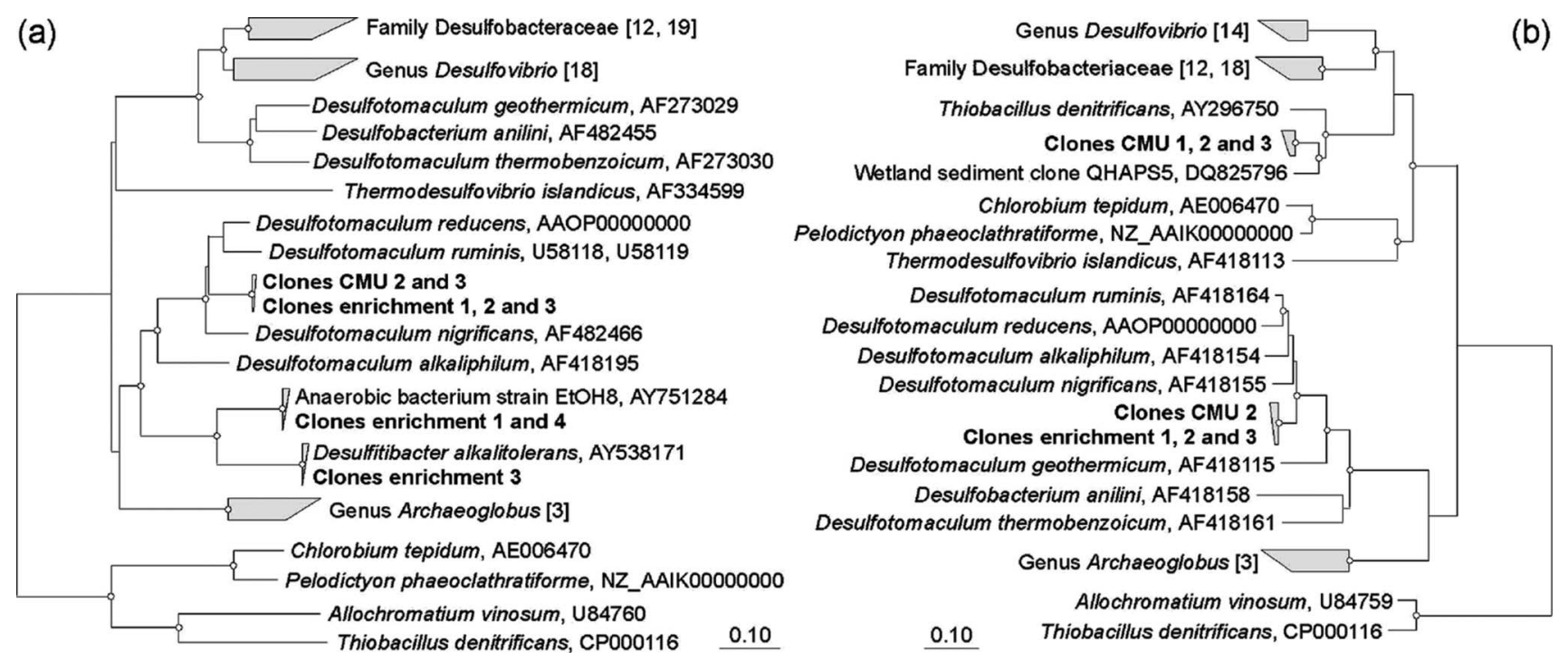

Figure 2. (a,b) Distance-matrix-based trees showing the phylogenetic affiliation of deduced $d \operatorname{sr} A B$ (a) and aps $A$ (b) amino acid sequences retrieved from biofilm and enrichment cultures from reactors 1-4 (all shown in bold). Nodes receiving $>80 \%$ bootstrap support are marked by open circles. Numerals in square brackets indicate the numbers of genera and/or named species constituting the respective grouping. Bars represent $10 \%$ estimated sequence divergence.

\section{Detection and identification of SRB}

The occurrence and activity of SRB in biofilms from CMUs 1-4 was inferred from the presence of sulfide on mild steel coupons (results not shown). Two different approaches were used for sensitive detection and identification of SRB: PCR-based retrieval of the functional marker genes $d s r A B$ and aps $A$ and cultivation-based enrichment.

\section{dsrAB clone libraries}

PCR amplicons of $d s r A B$ were obtained from biofilm samples from CMU 2 and 4 as well as from enrichment cultures. A single sequence type, affiliated with members of the Gram-positive SRB genus Desulfotomaculum, occurred among the 36 and 21 dsr $A B$ sequences retrieved from the biofilm samples originating from CMU 2 and 4, respectively (Figure 2). This phylotype was also present in enrichment cultures from CMU 1, 2, and 3 from each of which 21-25 dsr $A B$ sequences were retrieved. Furthermore, sequences highly similar to the Gram-positive bacterium Desulfitibacter alkalitolerans and strain $\mathrm{EtOH} 8$ were obtained from the enrichment cultures (Figure 2a). These bacteria were originally isolated from a heating system and represent alkali-tolerant sulfite-reducing species, which are unable to grow by reducing sulfate and were probably present in the enrichment cultures due to their fermentative capacities. However, reduction of 
thiosulfate, sulfite, or elementary sulfur produced by sulfide oxidation might also occur, since these sulfur species likely exist in the heating systems due to the introduction of oxygen into the otherwise reduced environment (Nielsen et al. 2006; Kjeldsen et al. 2007).

\section{apsA clone libraries}

PCR amplicons of apsA were obtained from biofilm samples from CMU1, 2, and 3 as well as from enrichment cultures. Unexpectedly, most of the clones turned out not to carry aps $A$ inserts even though the inserts were of the expected size. Two different aps $A$ phylotypes were identified from the biofilm samples. One clustered with the sulfide-oxidizer Thiobacillus denitrificans that was retrieved from CMU1, 2, and 3 (Figure 2b), while the other apsA phylotype clustered with members from the genus Desulfotomaculum. The latter most likely represented the same SRB as identified by the $\operatorname{dsr} A B$ approach and was also present in the enrichments.

\section{Corrosion measurements}

General and pitting corrosion were quantified to evaluate whether corrosion was induced on the mild steel coupons when oxygen and nutrients were added. General corrosion, as inferred from weight loss, was observed in all CMUs except from CMU 7 and 8 with continuous dosing of nutrients. Under alternating conditions, the general corrosion rates varied from 7 to $10 \mu \mathrm{m}$ year $^{?-1}$ after 56 days, with increased general corrosion rates after 109 days for the control and the combined treatment with nutrients (Table 5). CMUs 7 and 8 (continuously dosed with nutrients) were applied as positive controls to examine the effect of substrate addition on biofilm formation and biocorrosion in a nutrient limited environment.

Pitting corrosion was observed on the mild steel coupons when alternating conditions were introduced in CMU 1-5 and in the control CMU (Table 5) with pitting corrosion rates ranging from 143 to $254 \mu \mathrm{m}$ year $^{-1}$ after 56 days. The lowest rate was observed when only nutrients were added and the highest when the combined treatment with nutrients and oxygen occurred. The corrosion rates decreased for all CMUs to $80-107 \mu \mathrm{m} \mathrm{year}^{-1}$ toward the end of the experiment. The pitting corrosion rates were 10-40 times higher than the general corrosion rates showing that pitting corrosion was induced, when alternating conditions occurred. This was also supported by the PF showing that pitting corrosion was the predominant form of corrosion (data not shown).

Glutaraldehyde was added to one CMU as an abiotic control to reduce biofilm formation. However, while reducing the biofilm formation the corrosion rate was not reduced. In other studies where glutaraldehyde was applied, similar corrosive effects of the nonoxidizing biocide has been observed (Fang et al. 2002; Vizcaino-Alcaide et al. 2003). In the study by Vizcaino-Alcaide et al. (2003), corrosion due to glutaraldehyde occurred on a hospital scalpel, when organic matter was present on the steel surface, but not on a clean surface. Also, a study by Fang et al. (2002) showed that mild steel surfaces in the presence of glutaraldehyde still experienced biofilm growth and corrosion. An additional reason for corrosion in the CMU dosed with glutaraldehyde might be the removal of magnetite by glutaraldehyde that was deposited on the mild steel coupons due to the chemical conditions in the heating water (observed visually). In the positive control CMUs (7-8), corrosion was not observed, which might have been due to formation of a protective biofilm when yeast extract was fed in the continuous feed medium. In other laboratory studies, the use of yeast extract in culture media has been shown to interfere with electrochemical corrosion measurements (Webster and Newman 1994; Little et al. 2007).

Qualitative observations of the corrosion revealed that CMUs dosed with either oxygenated heating water (CMU 2) or oxygen in combination with nutrients (CMU 3) experienced pitting corrosion

Table 5. General and pitting corrosion rates on mild steel coupons exposed to alternating conditions.

\begin{tabular}{|c|c|c|c|c|c|c|}
\hline \multirow[b]{2}{*}{ Treatment } & \multicolumn{3}{|c|}{ General corrosion rate $\left(\mu \mathrm{m}\right.$ year $\left.^{-1}\right)$} & \multicolumn{3}{|c|}{ Pitting corrosion rate $\left(\mu \mathrm{m}\right.$ year $\left.^{-1}\right)$} \\
\hline & 56 days & 109 days & 129 days & 56 days & 109 days & 129 days \\
\hline Organic matter & $7.0(1.5)$ & $6.9(2.6)$ & 1.6 & $143.4(12.8)$ & $98.8(7.9)$ & $80.4(9.0)$ \\
\hline $\mathrm{O}_{2}$ & $9.0(0.1)$ & $8.5(2.5)$ & $5.6(1.0)$ & $192.9(52.9)$ & $110.5(11.9)$ & $88.2(17.5)$ \\
\hline Organic matter $/ \mathrm{O}_{2}$ & $8.9(1.0)$ & $13.3(4.1)$ & $5.5(0.8)$ & $253.9(31.6)$ & $115.9(8.5)$ & $107.2(14.0)$ \\
\hline Control & $10.4(2.6)$ & $12.2(2.5)$ & $8.0(3.5)$ & $177.3(24.7)$ & $100.5(10.3)$ & $85.7(20.4)$ \\
\hline Glutaraldehyde & $7.2(9.1)^{\mathrm{a}}$ & $2.9(0.2)^{b}$ & - & $247.5(35.0)^{\mathrm{a}}$ & $100.2(4.6)^{\mathrm{b}}$ & - \\
\hline
\end{tabular}

Corrosion was not observed when continuous dosing occurred. The $95 \%$ confidence interval is shown.

Sampling was performed after ${ }^{\mathrm{a}} 41$ days and ${ }^{\mathrm{b}} 94$ days instead of the main sampling dates due to a later start. 
starting as few and separated pits (data not shown). During the experiment the pits increased in size, and some of them merged and developed into wide and deep pits. In the control (CMU 4) and CMU 1 dosed with nutrients the pits remained separated, but increased in size and merged into lines across the coupons.

Statistical tests were performed to evaluate whether the increased pitting corrosion rates for the CMU supplied with a combination of alternating oxygen and nutrients (CMU 3) were statistically significant compared to the other treatments after exposure for 56, 109, and 129 days, respectively. The corrosion rates from the combined treatment (CMU 3) exceeded the pitting corrosion rates from CMU supplied with nutrients (CMU 1) at all sampling times. In comparison, statistically significant values $(p<0.05)$ were only obtained at day 56 for the CMU 2 supplied with oxygen and at days 56 and 109 for the control (CMU 4). At the termination of the experiment at day 129, the combined treatment had an impact on the pitting corrosion $(90 \%$ confidence level) compared to the control and the other CMUs. The data also showed that oxygen in combination with nutrients increased the pitting corrosion rates, while addition of nutrients alone decreased the corrosion compared to the control. For the oxygen treatment the pitting corrosion rates were unchanged compared to the control.

When comparing the corrosion rates and the total number of bacteria for the CMUs treated by alternating dosing, the highest number of bacteria was observed when the highest pitting corrosion rates were present. The lowest numbers of bacteria were present when glutaraldehyde was added (CMU 5) and in the control (CMU 4). This former observation did not correspond with the lowest pitting corrosion rates that were present when nutrients were added intermittently, but could be explained by corrosion due to glutaraldehyde even though glutaraldehyde reduced the number of biofilm bacteria present. Similar corrosive effects were observed in a study by Fang et al. (2002), where it was shown that corrosion of mild steel occurred in the presence of glutaraldehyde due to the presence of layers of extracellular polymeric substances (EPS) formed at the metal surface between clumps of biofilm. Due to this colonization pattern electrochemical gradients were formed, where the biofilm behaved as cathode and the EPS as anode causing biocorrosion of the mild steel surface (Fang et al. 2002). Thus, glutaraldehyde can act as a biocide and reduce the number of bacteria, while the remaining bacteria and EPS produced can form electrochemical gradients at the surface and cause corrosion, which might have been the case in this study of the heating system.

\section{Discussion \\ Influence of alternating conditions on bacterial diversity}

Only minor differences in the microbial populations were observed between the CMUs despite major differences in the nutrient dosing regimes. Betaproteobacteria were the dominant bacterial groups in the biofilm, while SRB were detected in low numbers with FISH and qualitatively with the functional genes for SRB detection $d s r A B$ and aps $A$.

A Gram-positive SRB (Desulfotomaculum sp.) was identified, when the $\operatorname{dsr} A B$ and aps $A$ approach was applied to CMUs 1-4, while the FISH analysis indicated the presence of Gram-negative $\mathrm{SRB}$ in CMU 7 and 8. Furthermore, $\operatorname{dsr} A B$ and aps $A$ gene sequence types closely related to Desulfitibacter alkalitolerans, strain EtOH8 and Thiobacillus denitrificans were detected in CMUs 1-4. D. alkalitolerans and strain EtOH8 (both isolated from heating systems) are Gram-positive, alkali-tolerant, sulfite- and thiosulfatereducers unable to reduce sulfate, with $\mathrm{pH}$ growth optima around $\mathrm{pH}$ 9.0-9.5 (Nielsen et al. 2006). $T$. denitrificans is a sulfide-oxidizer and, thus, possibly forming a sulfur cycle together with the SRB and the sulfite-reducers in the biofilms. As described in earlier biocorrosion studies, the simultaneous presence of reduced sulfur compounds and oxygen can create a very corrosive environment because of the formation of elementary sulfur, polysulfides, and other compounds which can establish an autocatalytic corrosion process that can take place even in the absence of active SRB (Lee et al. 1993; Nielsen et al. 1993).

The general bacterial diversity analyzed by DGGE showed that bacteria closely related to Alcaligenaceae bacterium BL-169 isolated from groundwater contaminated with chloroethanes and other solvents (Bowman et al. 2006) as well as Denitratisoma oestradiolicum and Bellilinea caldifistulae.The former is a denitrifying oestradiol-degrading bacterium (Fahrbach et al. 2006) and the latter a strictly anaerobic, filamentous bacterium isolated from a methanogenic consortium (Yamada et al. 2007). In the current as well as in the previous study of heating systems, several bacteria were identified that had a high similarity to bacteria degrading complex organic substances such as polychlorinated biphenyls, polycyclic aromatic hydrocarbons, and phenols (Kjellerup et al. 2005). As described by Kjellerup et al. (2005) the nutrient poor conditions in the heating systems fit well with this bacterial physiology. Additional bacteria were most closely related (93-96\% sequence identity) to: (1) the thermophilic aerobe Caldimonas taiwanensis (Chen et al. 2005). Although not tested for $C$. taiwanensis the other member of the genus Caldimonas, 
C. manganoxidans oxidize manganese and is moderately alkaliphilic (Takeda et al. 2002); (2) the mesophilic aerobic $\mathrm{H}_{2}$-oxidizer Hydrogenphaga pseudoflava (Willems et al. 1989); notably other species belonging to this genus grow by oxidizing thiosulfate and by fermentation (Chung et al. 2007); (3) the mesophilic photothrophic sulfide-oxidizer Blastochloris sulfoviridis, which also grows heterotrophically under microaerophilic conditions (Hiraishi 1997). The presence of a biofilm consisting of diverse microbial populations together with alternating conditions of oxygen and nutrients even at a microaerophilic level was shown to cause corrosion in this heating system. While the bacterial diversity seemed not to be influenced by the operational conditions, the alternating nutrient and oxygen dosing created microniches or local environments in the biofilm that lead to the observed biocorrosion.

\section{Effect of microaerophilic vs anaerobic/anoxic conditions}

Alternating microaerophilic conditions were established when oxygen was added intermittently to CMUs installed in the heating system. In combination with alternating nutrient addition, this induced a corrosive environment with high numbers of biofilm bacteria (Table 2), evidently causing elevated pitting corrosion on the mild steel coupons. Pitting corrosion is more commonly observed than general corrosion when bacteria are involved and is often referred to as biocorrosion (Little et al. 1992). In an earlier study of heating systems similar corrosion patterns were observed (Kjellerup et al. 2004). The alternating conditions used in this study simulated in situ conditions in heating systems since continuous contamination with oxygen and nutrients rarely happens (Danish Council of District Heating 1999). The contaminant sources have previously been related to improper treatment of the supply water, leaks into the system from domestic hot water tanks or leaks of air into the system in cases of inspection, repair or maintenance work. Nutrient sources also include installation and repair of heating system components, where protective layers of oil and grease are applied to reduce chemically induced corrosion and scale formation during transport and handling (Olesen et al. 2003).

While it might be impossible to prevent biofilm formation even in nutrient limited systems such as heating systems, it might be possible to control corrosion by benefitting from protective bacterial biofilms (Little et al. 2007; Zuo 2007). Common for the strategies described by Little et al. (2007) and Zuo (2007) was the ability to control the conditions in the systems in order to benefit from the protective characteristics of the biofilm. In heating systems, it is difficult to maintain conditions that would imply the presence of stable and protective biofilms due to a continuous supply of nutrients in the absence of oxygen. In addition, this study showed that severe pitting corrosion occurred in the heating system when nutrients were added intermittently together with small amounts of oxygen thus causing microaerophilic conditions. These alternating conditions resembled the conditions of a full scale heating system and showed that sources of oxygen and nutrients should be limited in order to control biocorrosion. This is particularly important because the results indicate that corrosion was not due to the presence of specific bacterial groups in the biofilm but mainly caused by the effects of the induced alternating oxygen and nutrient conditions on the metabolic state of the microbial populations thus changing the chemistry of the system.

\section{Acknowledgments}

The authors thank Susanne Bielidt and Merete Fredsgaard for technical assistance and patience in handling the CMUs connected to the heating system. The Danish Energy Authority (Program EFP-2000) and The Danish Research Council supported this study under the framework program 'Activity and Diversity in Complex Microbial Systems'.

\section{References}

Abildgaard L, Nielsen MB, Kjeldsen KU, Ingvorsen K. 2006. Desulfovibrio alkalitolerans sp. nov., a novel alkalitolerant, sulphate-reducing bacterium isolated from district heating water. Int J Syst Evol Microbiol 56:1019-1024.

Amann R, Ludwig W, Schleifer K-H. 1995. Phylogenetic identification and in situ detection of individual microbial cells without cultivation. Microbiol Rev 59:143169.

Amann RI, Binder BJ, Olson RJ, Chisholm SW, Devereux R, Stahl DA. 1990. Combination of 16S rRNA-targeted oligonucleotide probes with flow cytometry for analyzing mixed microbial populations. Appl Environ Eng 56: 1919-1925.

American Public Health Association/American Water Works Association/Water Environment Federation WD. 1995. (USA). Standard methods for the examination of water and wastewater.

ASTM. 1994. Standard guide for examination and evaluation of pitting corrosion. p. G46-94.

ASTM. 1999. Standard practice for preparing, and evaluating corrosion test specimens. p. G1-90.

Bowman KS, Moe WM, Rash BA, Bae HS, Rainey FA. 2006. Bacterial diversity of an acidic Louisiana groundwater contaminated by dense nonaqueous-phase liquid containing chloroethanes and other solvents. FEMS Microbiol Ecol 58:120-133.

Chen WM, Chang JS, Chiu CH, Chang SC, Chen WC, Jiang CM. 2005. Caldimonas taiwanensis sp. nov., a amylase producing bacterium isolated from a hot spring. Syst Appl Microbiol 28:415-420. 
Chung BS, Ryu SH, Park M, Jeon Y, Chung YR, Jeon CO. 2007. Hydrogenophaga caeni sp. nov., isolated from activated sludge. Int J Syst Evol Microbiol 57:1126-1130.

Daims H, Brühl A, Amann R, Schleiffer K-H, Wagner M. 1999. The Domain-specific probe EUB338 is insufficient for the detection of all bacteria: development and evaluation of a more comprehensive probe set. System Appl Microbiol 22:434-444.

Danish Council of District Heating D. Recommendations for water quality in Danish district heating systems. Frederisksberg, Denmark: Danish Council of District Heating.

Dilling W, Cypionka H. 1990. Aerobic respiration in sulfatereducing bacteria. FEMS Microbiol Lett 71:123-128.

Dinh HT, Kuever J, Mussmann M, Hassel AW, Stratmann M, Widdel F. 2004. Iron corrosion by novel anaerobic microorganisms. Nature 427:829-832.

Domingo JWS, Berry CJ, Summer M, Fliermans CB. 1998. Microbiology of spent nuclear fuel storage basins. Curr Microbiol 37:387-394.

Eager RG, Theis AB, Turakhia MH, Characklis WG. 1986. Glutaraldehyde: impact on corrosion causing biofilms. Corrosion 86. Houston (TX): NACE Press. Paper No. 125.

Eschenhagen M, Schuppler M, Röske I. 2003. Molecular characterization of the microbial community structure in two activated sludge systems for the advanced treatment of domestic effluents. Water Res 37:3224-3232.

Fahrbach M, Kuever J, Meinke R, Kampfer P, Hollender J. 2006. Denitratisoma oestradiolicum gen. nov., sp. nov., a 17 -oestradiol-degrading, denitrifying betaproteobacterium. Int J Syst Evol Microbiol 56:1547-1552.

Fang HH, Xu LC, Chan KY. 2002. Effects of toxic metals and chemicals on biofilm and biocorrosion. Water Res 36:4709-4716.

Flemming H-C. 1996. Economical and technical overview. In: Heitz E, Flemming H-C, Sand W, Microbially influenced corrosion of materials. New York: Springer. p. 5-14.

Friedrich MW. 2002. Phylogenetic analysis reveals multiple lateral transfers of adenosine- $5^{\prime}$-phosphosulfate reductase genes among sulfate-reducing microorganisms. J Bacteriol 184:278-289.

Goeres DM, Nielsen PH, Smidt HD, Frølund B. 1998. The effect of alkaline $\mathrm{pH}$ conditions on a sulphate reducing consortium from a Danish district heating plant. Biofouling 12:273-286.

Griebe T, Flemming H-C. 2000. Rotating annular reactors for controlled growth of biofilms. In: Flemming H-C, Szewzyk U, Griebe T, editors. Biofilms - investigative methods and applications. Lancaster, Pennsylvania: Technomic Publishing Company, Inc. p. 23-40.

Hamilton WA. 2003. Microbially influenced corrosion as a model system for the study of metal microbe interactions: a unifying electron transfer hypothesis. Biofouling 19:65-76.

Heitz E. 1996. Electrochemical and chemical mechanisms. In: Heitz E, Flemming H-C, Sand W, editors. Microbially influenced corrosion of materials. New York: Springer. p. $27-38$.

Hiraishi A. 1997. Transfer of the bacteriochlorophyll b-containing phototrophic bacteria Rhodopseudomonas viridis and Rhodopseudomonas sulfoviridis to the genus Blastochloris gen. nov. Int J Syst Bacteriol 47:217-219.

Itoh T, Okabe S, Satoh H, Watanabe Y. 2002. Successional development of sulfate-reducing bacterial populations and their activities in a wastewater biofilm growing under microaerophilic conditions. Appl Environ Microbiol 68:1392-1402.
Jack TR, Westlake DWS. 1995. Control in industrial settings. In: Barton LL, editor. Sulfate-reducing bacteria. New York: Plenum Press. p. 265-292.

Kjeldsen KU, Joulian C, Ingvorsen K. 2004. Oxygen tolerance of sulfate-reducing bacteria in activated sludge. Environ Sci Technol 38:2038-2043.

Kjeldsen KU, Kjellerup BV, Egli K, Frolund B, Nielsen PH, Ingvorsen K. 2007. Phylogenetic and functional diversity of bacteria in biofilms from metal surfaces of an alkaline district heating system. FEMS Microbiol Ecol 61:384 397.

Kjellerup BV, Olesen BH, Frølund B, Nielsen PH. 2004. Potential of biocorrosion in Danish district heating systems. Mater Corrosion 55:543-547.

Kjellerup BV, Gudmonsson G, Sowers K, Nielsen PH. 2006. Evaluation of analytical methods for determining the distribution of biofilm and active bacteria in a commercial heating system. Biofouling 22:145-151.

Kjellerup BV, Olesen BH, Nielsen JL, Frølund B, Ødum S, Nielsen PH. 2003. Monitoring and characterisation of bacteria in corroding district heating systems using fluorescence in situ hybridisation and microautoradiography. Water Sci Technol 47:117-122.

Kjellerup BV, Thomsen TR, Nielsen JL, Olesen BH, Frølund B, Nielsen PH. 2005. Microbial diversity in biofilms from corroding heating systems. Biofouling 21:19-29.

Krekeler D, Teske A, Cypionka H. 1998. Strategies of sulfate-reducing bacteria to escape oxygen stress in a cyanobacterial mat. FEMS Microbiol Ecol 25:89-96.

Lee W, de Beer D. 1995. Oxygen and pH microprofiles above corroding mild steel covered with a biofilm. Biofouling 8:273-280.

Lee W, Lewandowski Z, Morrison M, Characklis WG, Avci R, Nielsen PH. 1993. Corrosion of mild steel underneath aerobic biofilms containing sulfate-reducing bacteria. II. At low dissolved oxygen concentration. Biofouling 7:217239.

Little B, Wagner P, Mansfeld F. 1992. An overview of microbiologically influenced corrosion. Electrochim Acta 37:2185-2194.

Little BJ, Ray RI, Pope RK. 2000. Relationships between corrosion and the biological sulfur cycle: a review. Corrosion 56:433-443.

Little B, Lee J, Ray R. 2007. A review of 'green' strategies to prevent or mitigate microbiologically influenced corrosion. Biofouling 23:87-97.

Loy A, Horn M, Wagner M. 2003. probeBase - an online resource for rRNA-targeted oligonucleotide probes. Nucleic Acids Res 31:514-516.

Lucker S, Steger D, Kjeldsen KU, MacGregor BJ, Wagner M, Loy A. 2007. Improved 16S rRNA-targeted probe set for analysis of sulfate-reducing bacteria by fluorescence in situ hybridization. J Microbiol Methods 69:523-528.

Ludwig W, Strunk O, Westram R, Richter L, Meier H, Yadhukumar, Buchner A, Lai T, Steppi S, Jobb G, et al. 2004. ARB: a software environment for sequence data. Nucleic Acids Res 32:1363-1371.

Manz W, Amann R, Ludwig W, Wagner M, Schleifer K-H. 1992. Phylogenetic oligodeoxynucleotide probes for the major subclasses of proteobacteria. Syst Appl Microbiol 15:593-600.

Manz W, Amann R, Ludwig W, Vancanneyt M, Schleifer K-H. 1996. Application of a suite of 16S rRNAspecific oligonucleotide probes designed to investigate bacteria of the phylum cytophage-flavobacter-bacteroides in the natural environment. Microbiology 142:1097-1106. 
Metropolitan Copenhagen Heating Transmission Company C. 1994. Guidelines for water quality. Frederiksberg, Denmark: Metropolitan Copenhagen Heating Transmission Company.

Minz D, Fishbain S, Green SJ, Muyzer G, Cohen Y, Rittmann BR, A SD. 1999. Unexpected population distribution in a microbial mat community: sulfatereducing bacteria localized to the highly oxic chemocline in contrast to a eukaryotic preference for anoxia. Appl Environ Microbiol 65:4659-4665.

Muyzer G, De Wall EC, Utterlinden AG. 1993. Profiling of complex microbial populations by denaturing gradient electrophoresis analysis of polymerase chain reactionamplified genes coding for 16S rRNA. Appl Environ Microbiol 59:695-700.

Neef A. 1997. Anwendung der in situ-einzelzell-identifizierung von bakterien zur populationsanalyse in komplesen mikrobiellen biozönosen. Munich, Germany: Technical University of Munich.

Nielsen PH, Lee W, Lewandowski ZL, Morison M, Characklis WG. 2006. Desulfitibacter alkalitolerans gen. nov., sp. nov., an anaerobic, alkalitolerant, sulfitereducing bacterium isolated from a district heating plant. Int J Syst Evol Microbiol 56:2831-2836.

Nielsen PH, Lee W, Lewandowski ZL, Morison M, Characklis WG. 1993. Corrosion of mild steel in an alternating oxic and anoxic biofilm. Biofouling 7:267-284.

Olesen BH, Lorenzen J, Kjellerup BV, Nielsen PH, Frølund B. 2003. MIC mitigation in a $100 \mathrm{MW}$ district heating peak load unit. Water Sci Technol 49:99-105.

Pernthaler A, Pernthaler J, Amann R. 2002. Fluorescence in situ hybridization and catalyzed reporter deposition for the identification of marine bacteria. Appl Environ Microbiol 68:3094-3101.

Rabus R, Fukui M, Wilkes H, Widdel F. 1996. Degradative capacities and 16S rRNA-targeted whole-cell hybridization of sulfate-reducing bacteria in an anaerobic enrichment culture utilizing alkylbenzenes from crude oil. Appl Environ Microbiol 62:3605-3613.

Rozanova EP, Dubinina GA, Lebedeva EV, Suntsove LA, Lipovskikh VM, Tsvetkov NN. 2003. Microorganisms in heat supply lines and internal corrosion of steel pipes. Mikrobiologiia 72:212-220.

Stahl DA, Amann R. 1991. Development and application of nucleic acid probes. In: Starckebrandt E, Godfellow M, editors. Nucleic acid techniques in bacterial systematics. Wiley. p. 205-248.

Stahl DA, Loy A, Wagner M. 2007. Molecular strategies for studies of natural populations of sulphate-reducing microorganisms. In: Barton LL, Hamilton WA, editors. Sulphate-reducing bacteria; environmental and engineered systems. Cambridge (UK): Cambridge University Press. p. $39-116$.

Swofford DL. 2003. PAUP*. Phylogenetic Analysis Using Parsimony (*and Other Methods). Version 4. Sunderland (MA): Sinauer Associates.

Takeda M, Kamagata Y, Ghiorse WC, Hanada S, Koizumi J. 2002. Caldimonas manganoxidans gen. nov., sp. nov., a poly(3-hydroxybutyrate)-degrading, manganese-oxidizing thermophile. Int J Syst Evol Microbiol 52:895900.

Teske A, Ramsing NB, Habicht K, Fukui M, Küver J, Jørgensen BB, Cohen Y. 1998. Sulfate-reducing bacteria and their activities in cyanobacterial mats of Solar Lake (Sinai, Egypt). Appl Environ Microbiol 64:2943-2951.
UBM. 2009. Microfocus UBM [Internet]. Finland: University of Tampere; [cited 2009 Jul 11]. Available from: http:// www . tut.fi/units/ms/elm/laitteet/laserprofilometer(eng). htm.

Videla HA, Herrera LK. 2005. Microbiologically influenced corrosion: looking to the future. Int Microbiol 8:169-180.

Videla HA, Sautú AE, Saravia SGGd, Guiamet PS, Mele MFLd, Gaylarde CC, Beech IB. 1991. Impact of glutaraldehyde on biofouling and MIC of different steels. A laboratory assessment. Corrosion 91. Houston (TX): NACE Press. Paper No. 105.

Vizcaino-Alcaide MJ, Herruzo-Cabrera R, FernandezAcenero MJ. 2003. Comparison of the disinfectant efficacy of Perasafe and $2 \%$ glutaraldehyde in in vitro tests. J Hosp Infect 53:124-128.

Wagner M, Horn M, Daims H. 2003. Fluorescence in situ hybridisation for the identification and characterisation of prokaryotes. Curr Opin Microbiol 6:302-309.

Wagner M, Amann R, Lemmer H, Schleifer K. 1993. Probing activated sludge with oligonucleotides specific for Proteobacteria: inadequacy of culture-dependent methods for describing microbial community structure. Appl Environ Microbiol 59:1520-1525.

Wallner G, Amann R, Beisker W. 1993. Optimizing fluorescent in situ hybridization with rRNA-targeted oligonucleotide probes for flow cytometric identification of microorganisms. Cytometry 14:136-143.

Webster BJ, Newman RC. 1994. Producing rapid sulfatereducing bacteria-influenced corrosion in the laboratory. In: Kearns J, Little BJ, editors. Microbiologically influenced corrosion testing. Philadelphia (PA): ASTM Publication. p. 28-41.

Wilderer PA, Bungartz H-J, Lemmer H, Wagner M, Keller J, Wuertz S. 2002. Modern scientific methods and their potential in wastewater science and technology. Water Res 36:370-393.

Willems A, Busse J, Goor M, Pot B, Falsen E, Jantzen E, Hoste B, Gillis M, Kersters K, Auling G, et al. 1989. Hydrogenophaga, a new genus of hydrogen-oxidizing bacteria that includes Hydrogenophaga flava comb. nov. (formerly Pseudomonas flava), Hydrogenophaga palleronii (formerly Pseudomonas palleronii), Hydrogenophaga pseudoflava (formerly Pseudomonas pseudoflava and "Pseudomonas carboxydoflava") and Hydrogenophaga taeniospiralis (formerly Pseudomonas taeniospiralis). Int J Syst Bacteriol 39:319-333.

Yamada T, Imachi H, Ohashi A, Harada H, Hanada S, Kamagata Y, Sekiguchi Y. 2007. Bellilinea caldifistulae gen. nov., sp. nov. and Longilinea arvoryzae gen. nov., sp. nov., strictly anaerobic, filamentous bacteria of the phylum Chloroflexi isolated from methanogenic propionate-degrading consortia. Int J Syst Evol Microbiol 57:2299-2306.

Zhang T, Fang HHP, Ko BCB. 2003. Methanogen population in a marine biofilm corrosive to mild steel. Appl Microbiol Biotechnol 63:101-106.

Zuo R. 2007. Biofilms: strategies for metal corrosion inhibition employing microorganisms. Appl Microbiol Biotechnol 76:1245-1253. 